\title{
A CYCLONIC EDDY NORTH OF LOMBOK *)
}

by

\author{
George Cresswell
}

\begin{abstract}
A satellite drifter that passed from south to north through Lombok Strait in early 1988 became trapped in a cyclonic eddy $100 \mathrm{~km}$ north of Lombok. The eddy, which was $130 \mathrm{~km}$ by $80 \mathrm{~km}$, had a rotation period of 10 days.

\section{INTRODUCTION}

While charts of currents drawn from ship drifts (e.g. Koninklijk Nederland's Meteorologisch Institute, 1949; Wyrtki, 1961) have made may large-scale features of the ocean circulation to be identifiable, they are not effective for identifying mesoscale features (of the order of $100 \mathrm{~km}$ scale length). This is sometimes because such features move, but more generally it is because the ship drifts were determined from celestial fixes at least half a day apart and then observations from many years were binned and averaged. But mesoscale features are probably important in the life cycles of marine creatures in a region. In this note we discuss an eddy north of Lombok that became apparent from the path followed by a satellite-tracked drifter.
\end{abstract}

\section{OBSERVATION}

The drifter, which was roughly torpedo-shaped, was $1.5 \mathrm{~m}$ long and had a parachute drogue at $20 \mathrm{~m}$ depth (Cresswell et al., 1979). It was originally released off northwestern Australia in January 1987, from whence it was carried westward in the South Equatorial Current. It was tracked by CLS-Argos.

In January 1988 the drifter came under the influence of the South Java Current (Soeriaatmadja, 1957) and was carried eastward at speeds up to $1.1 \mathrm{~ms}^{-1}$ (Quadfasel

**) Submitted to Marine Research in Indonesia

**) CSIRO Division of Oceanography, Hobart Tas 7001 Australia 
and Cresswell, 1992). On 4 February the drifter moved northward, reaching $1.5 \mathrm{~ms}^{-1}$, through Lombok strait into the Flores Sea (Figures 1 and 2). Small loopes in the drifter track to the northwest of Lombok indicated instabilities in the flow. The drifter then became trapped in an eddy $100 \mathrm{~km}$ north of Lombok for 15 days while it completed 1.5 rotations. It escaped from the eddy on 25 February and then entered the large lagoon Pulau-pulau Tengah, in which it moved very slowly until it ceased functioning on 12 March.

The addy, as revealed by the drifter, was $130 \mathrm{~km}$ by $80 \mathrm{~km}$ with its major axis eastwest. The water depth at the eddy was typically several hundred meters, so that the eddy was roughly bounded by the $1000 \mathrm{~m}$ contour on the south, Pulau-Pulau Tengah on the east and Pulau-Pulau Kangean on the west. The northern boundary seemed unrelated to topography. The mean speed of the drifter in the eddy was $0.4 \mathrm{~ms}^{-1}$. Its speed decreased to $0.2 \mathrm{~ms}^{-1}$ on 16 February when in traced out a $2 \mathrm{~km}$ diameter loop due to the flow becoming unstable as it passed Pulau-pulau Tengah (Figure2).

The temperature record from the drifter showed an afternoon heating effect of up to $3^{\circ} \mathrm{C}$, followed cooling overnight, when it was traveling slowly more than $200 \mathrm{~km}$ south of Java. The passage through Lombok Strait was accompanied by cooling of $2^{\circ} \mathrm{C}$, probably due to upwelling induced by the flow. In Pulau-pulau Tengah Lagoon, the diurnal temperature oscillations were up to $6^{\circ} \mathrm{C}$.

\section{DISCUSSION}

Current meters moored in Lombok strait (Murray and Arief, 1988) showed reversals of the dominant southward flow in the cyclone season, in particular in February/March 1985 and in January 1986, and speeds at the $35 \mathrm{~m}$ instrument reached $1 \mathrm{~ms}^{-1}$. The northward passage of the drifter through the strait in February 1988 is consistent with those observations. In the Flores Sea, westerly winds prevail hum December to March. They drive a uniform current to the east, with this current being intensified along the north coast of the Lesser Sunda Island Bali, Lombok, Sumbawa and Flores (Wrytki,1961).The drifter track gives a conflicting picture: between leaving Lombok strait and entering the eddy it provided no evidence of an eastward current. The conflicting evidence points to the need for more work in the region and leaves the question-was the February 1988 period unusual? 


\section{REFERENCES}

Cresswell, G., R., G.T. Richardson, J.E. Wood, and R. Watts, 1979. The CSIRO satellite-tracked 'torpedo' buoy Division of Fish eries and Oceanography Report, CSIRO, Cromulla $82: 13$ pp.

Koninklijk Nederland Meteorologisch Institute, 1949. Seas Around Australia. Oceanographic and Meteorological Data, De Bilt 124 : 77 pp.

Murray, S.P. and D. Arief, 1988. Through flow into the Indian Ocean through the Lombok Strait, January. 1985 - January 1986. Nature 333 : 444-447.

Quadfasel, D., and G.R. Cresswell, 1992. A note on the seasonal variability of the South Java Current. Journal of Geophysical Research 97: 3685-3688.

Soeriaatmadja, R.E., 1957 The Coastal Current South of Java. Marine Research in Indonesia 3 : 41-55.

Wyrtki, K., 1961. Physical Oceanography of the Southeast Asian. Waters NAGA Rep. 2: 195 pp. 

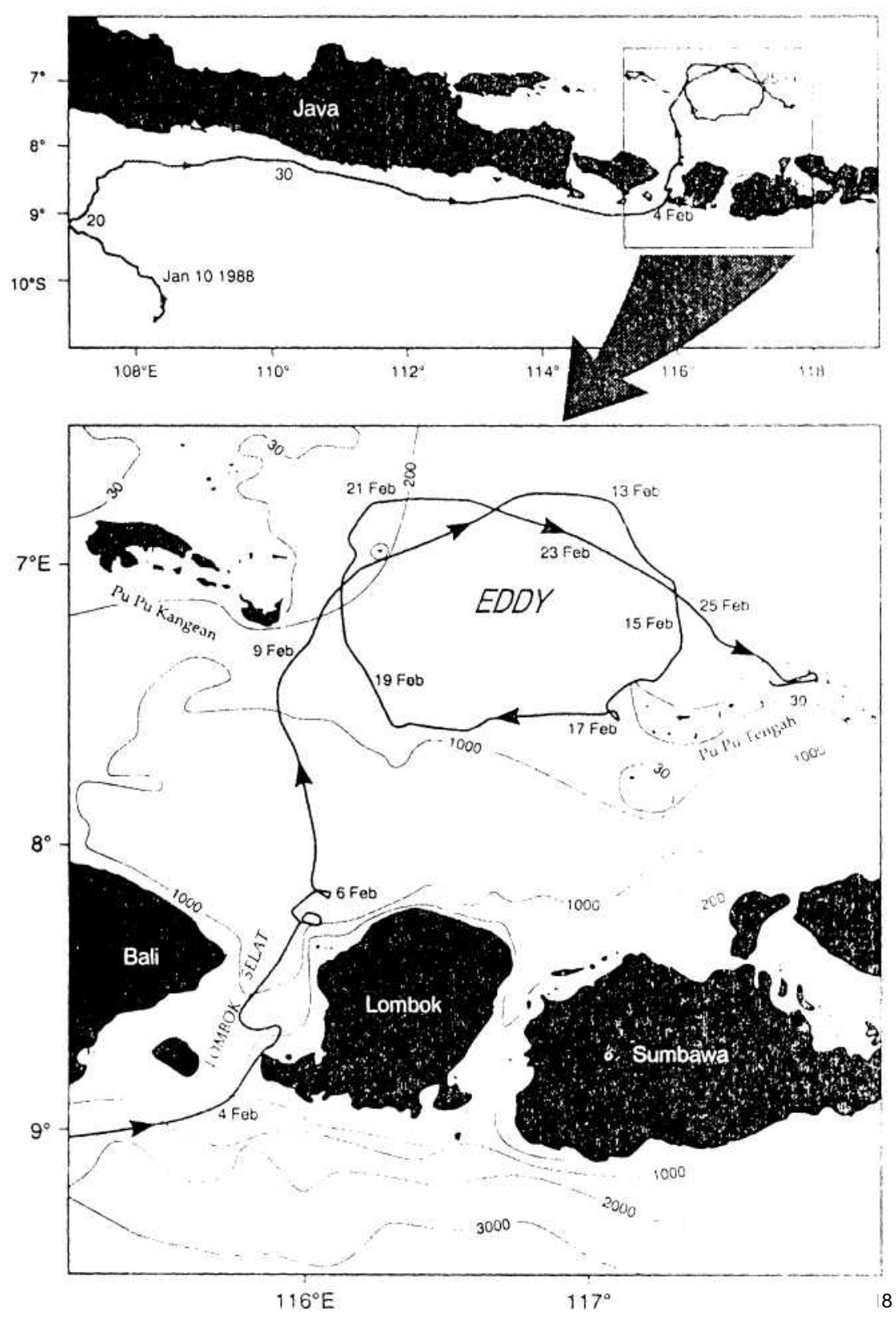

Figure 1. The path of the drifter through Lombok Strait and into the cyclonic eddy in the Flores Sea. 

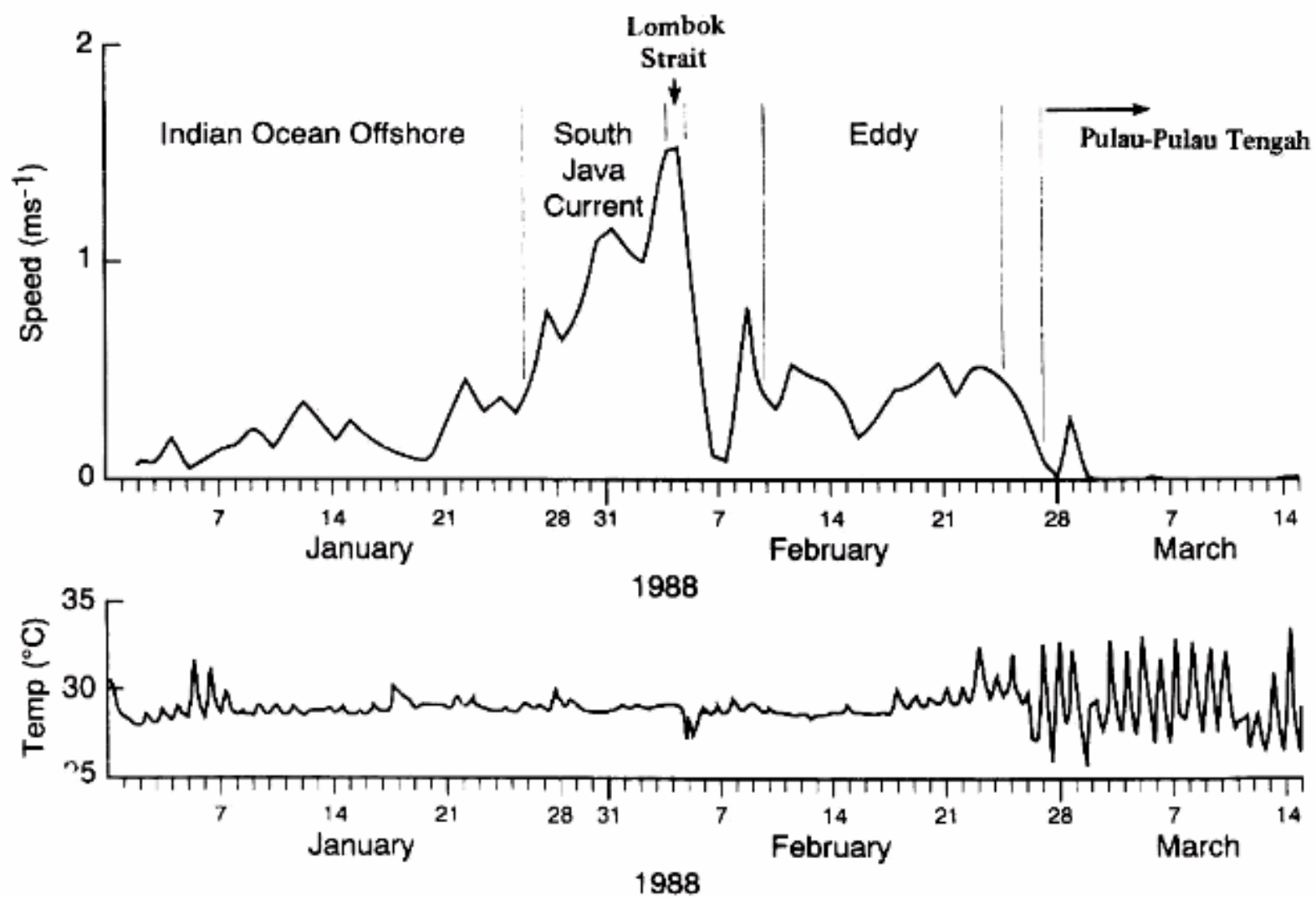

Figure 2. Time series of the speed of the driver and the sea surface temperatures it measured 